\title{
SYNTHESIS, CHARACTERIZATION, AND ANTICANCER ACTIVITY OF SOME NOVEL ACRIDINE DERIVATIVES
}

\begin{abstract}
SWETHA PADIGELA ${ }^{1}$, BHAGAVAN RAJU RMㄹ ${ }^{2}$ RAJENDRA PRASAD VVS ${ }^{3 *}$
${ }^{1}$ Department of Pharmaceutical Chemistry, Vishnu Institute of Pharmaceutical Educational and Research, Narsapur, Telangana, India. ${ }^{2}$ Department of Pharmaceutical Chemistry, Sri Venkateshwara College of Pharmacy, Hyderabad, Telangana, India. ${ }^{3}$ Center for Molecular Cancer Research, Vishnu Institute of Pharmaceutical Educational and Research, Narsapur, Telangana, India. Email: rajendraprasad.vvs@viper.ac.in

Received: 31 March 2020, Revised and Accepted: 21 April 2020
\end{abstract}

ABSTRACT

Objective: The objective of the study was to synthesize and evaluate the anticancer activity of some novel acridine derivatives.

Methods: The present works involve condensation of acridine and various 2, 4-Thiazolidine-2,4-dione derivatives (2a-2h) with chloroacetyl chloride to give a novel acridine derivatives (5a-51), respectively.

Results: All the newly synthesized molecules (5a-5l) were characterized by FTIR, $\mathrm{H}^{1}$-NMR, and mass spectral analysis along with physical data. The biological potentials of the new synthesized compounds are evaluated for their in vitro anticancer activity by MTT assay.

Conclusion: The synthesized compounds 5a, 5f, and 5h exhibited good anticancer activity against MCF-7 and SKVO3 cancer cell lines at a concentration of $0.5 \mathrm{mg} / \mathrm{mL}^{-1}$.

Keywords: Acridine, 2, 4-Thiazolidinedione, Substituted aldehydes, Chloroacetyl chloride, Anticancer activity, MCF-7, SKVO3 cells.

(C) 2020 The Authors. Published by Innovare Academic Sciences Pvt Ltd. This is an open access article under the CC BY license (http://creativecommons. org/licenses/by/4. 0/) DOI: http://dx.doi.org/10.22159/ajpcr.2020.v13i6.35794

\section{INTRODUCTION}

Acridine was first isolated by Carl Grabe and Heinrich Caro in Germany in 1870 from high boiling fraction of coal tar [1]. The antimicrobial property [2] of acridine was discovered Ehrlich and Benda in 1917. Bernthsen reported the primary synthesis of acridine, in which diphenylamine was reacted with benzoic acid using zinc chloride and high temperatures. The synthesis of acridine and its derivatives has attracted considerable attention from untreated and medicinal chemists for many natural life, as a number of natural source have been report to have this heterocyclic nucleus. Chemically, acridine is also known by the names of dibenzopyridine, 2,3,5,6-dibenzopyridine, and 10-azaanthracene. It has an irritating odor and crystallizes in colorless to light yellow needles with melting point of $110^{\circ} \mathrm{C}$ and boiling point of $346^{\circ} \mathrm{C}$.

Acridineisaclass of heterocycliccompoundswhichmeritspecialattention because it belongs to a group of substances with activity in medicinal chemistry. This try cyclic nucleus derivatives are associated with antiinflammatory [3,4], anticancer [5], antimicrobial [6], antitubercular [7,8], antiparasitic [9], antimalarial [10,11], antiviral [12,13], and fungicidal activities [14]. The basic in nature of pyridine, quinoline, and acridine is more or less similar compounds which possess no benzene ring, one benzene ring, and two benzene rings, respectively. Acridone is the one of the heterocyclic compounds with a tricyclic ring having nitrogen at $10^{\text {th }}$ positions and keto group at $9^{\text {th }}$ positions with the formula $\mathrm{C}_{13} \mathrm{H}_{9} \mathrm{~N}$. Acridines are substituted derivative of the parent ring. It is a planar molecule so as to be structurally related to anthracene by means of one of the central $\mathrm{CH}$ groups replaced by nitrogen.

In view of the facts mentioned above and the wide applications of acridine molecule and its derivatives in medicinal chemistry, an attempt has been made to synthesize novel 3-(2-(9-oxoacridin-10(9H)-yl) acetyl)-5(benzylidene) thiazolidine-2,4-dione moiety as new anticancer agents.

\section{METHODS}

The synthesized compound was screened for sterile and anticancer activities. Fourier transform IR spectrometer (model Shimadzu 8700) in the range of 400-4000 $\mathrm{cm}^{-1}$ using $\mathrm{KBr}$ pellets and values are report in $\mathrm{cm}^{-1}$ and the spectra were interpreted. ${ }^{1} \mathrm{H}-\mathrm{NMR}$ spectra were recorded on DPX-200 MHz NMR spectrometer using DMSO- $\mathrm{d}_{6}$ and chemical shift $(\delta)$ is reported in parts per million downfield from internal reference tetramethylsilane and the spectra were interpreted. Mass spectra were record on mass spectrophotometer (model Shimadzu) by LC-MS and the spectra were interpreted. Pre-coated silica gel G plates were used to monitor the progress of reaction as well as to check the purity of the compound: n-Hexane: ethyl acetate (7:3) [15-17].

\section{General procedures}

Step 1: Preparation of $N$-phenyl anthracitic acid

In a $500 \mathrm{ml}$ round-bottomed flask are placed a combination of o-Chlorobenzoic acid (20 g, $0.128 \mathrm{~mol})$, Aniline $(11.8 \mathrm{ml}, 0.128 \mathrm{~mol}$ ) and Copper metallic (0.5 g). To this solution $100 \mathrm{ml}$ of amyl alcohol is delivered with constant stirring. To this mixture, dry potassium carbonate $(20 \mathrm{~g})$ was slowly added with stirring and the reaction mixture was allowed to reflux for $6 \mathrm{~h}$ in a light liquid paraffin oil bath at $135-140^{\circ} \mathrm{C}$. Then the amyl alcohol was removed by using steam distillation and combination poured into two $2 \mathrm{~L}$ of hot water and acidified with targeted hydrochloric acid. The bluish-black precipitate formed was filtered, washed with hot water, and collected. The crude acid was dissolved in aqueous $10 \%$ sodium hydroxide solution, boiled in the presence of activated charcoal, and filtered. On acidification of the filtrates with concentrated hydrochloric acid, light yellowish precipitate was obtained, which was washed with hot water. The crude acid was recrystallized from aqueous methanol to give a light yellow solid.

\section{Step 2: Preparation of acridin-9-one}

$\mathrm{N}$-Phenyl anthranilic acid (18 g, $0.084 \mathrm{~mol}$ ) was taken in a $500 \mathrm{ml}$ of round bottom flask to which polyphosphoric acid ( $180 \mathrm{~g}, 0.5327 \mathrm{~mol}$ ) was added, shaken well, and refluxed on a water bath at $100^{\circ} \mathrm{C}$ for $3 \mathrm{~h}$. Appearance of yellow color indicated the completion of reaction. Then, it was poured into $2 \mathrm{~L}$ of hot water and made alkaline by $25 \%$ ammonia solution. The yellow precipitate formed was filtered, washed with hot water, and collected. The crude acridin-9(10H)-one was recrystallized from acetic acid. 
Step 3: General procedure for thiazolidine-2, 4-dione

The equimolar quantity (1:1) of chloroacetic acid (56.4 g, $0.6 \mathrm{~mol}$ ) in $60 \mathrm{ml}$ of irrigate be added to the answer of thiourea ( $45.6 \mathrm{~g}, 0.6 \mathrm{~mol}$ ) in $60 \mathrm{ml}$ of water. The mixture be enthused for $15 \mathrm{~min}$ and precipitates were obtain after cooling. After that $60 \mathrm{ml}$ of concentrated hydrochloric acid was added slowly by using a dropping funnel. Once the mixture got transformed to solution shape, it was refluxed for 8-10 h at $100-110^{\circ} \mathrm{C}$. On cooling, the contents of the flask solidified to a come together of white needles. The manufactured goods were filtered and washed with water to take away traces of hydrochloric acid and dried. It was purified by recrystallization as of ethyl alcohol. Yield: 85\%; m.p.: $123-125^{\circ} \mathrm{C}$

Step 4: General procedure for the synthesis of 5-substituted-1,3thiazolidine-2,4-dione ( $4 a-4 h$ )

A combination of 2,4-thiazolidinedione 1 (1.17 g, $0.01 \mathrm{~mol}$ ), substitute benzaldehyde $(0.01 \mathrm{~mol})$, glacial acetic acid $(25 \mathrm{~mL})$, and fused sodium acetate $(0.18 \mathrm{~g})$ be refluxed for $1 \mathrm{~h}$ with occasional shaking. Cool, then, the reaction mixture be cooled to room temperature and it was poured in water $(250 \mathrm{~mL})$, the product obtained was filtered, wash with water, alcohol, and ether and was recrystallized with glacial acetic acid.

Step 5: 3-(2-(9-oxoacridin-10(9H)-yl) acetyl)-5-(benzylidene) thiazolidine-2,4-dione

A mixture of acridone (0.01 mol), 5-substituted-1,3-thiazolidine-2,4dione $(0.01 \mathrm{~mol})$, and chloroacetyl chloride $(0.01 \mathrm{~mol})$ in DMF $(30 \mathrm{ml})$ was refluxed for 3-4 h. Progress of reaction was monitor by TLC using n-Hexane: acetone (7:3). After the completion of response, the content was added to cold water. The solid product was obtained and filtered, dried, and purified by crystallization from ethanol (Table 1).

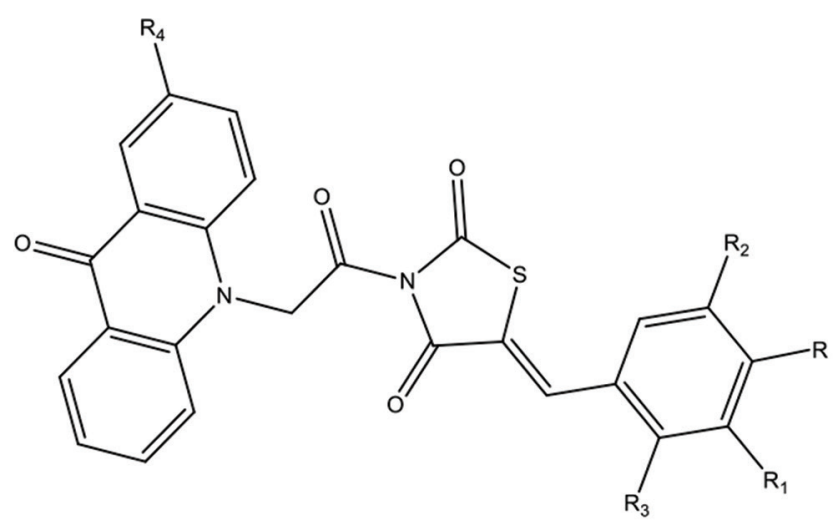

5 a-5l

5 a. (Z) - 3 - ( 2 - ( - 9- - xoacridin- $10(9 \mathrm{H})-\mathrm{yl})$ a c e tyl $)-5-(\mathrm{N}, \mathrm{N}-$ dimethyaminobenzylidenethiazo lidine-2,4-dione

M.P. 250-252 ${ }^{\circ} \mathrm{C}$; Mol. formula: $\mathrm{C}_{27} \mathrm{H}_{21} \mathrm{~N}_{3} \mathrm{O}_{4} \mathrm{~S}$, yield 76\%, 3038 (C-H Str, Ar), 2917, 2874 (C-H Str, Aliphatic), 2309 (C-S-C Str), 1716, 1702 (C=0 Str, thiazolidine-dione), 1523 (C=CH Str), 1429 (C=C Str, Ar), 1102 (C-N Str). ${ }^{1} \mathrm{H}$<smiles>[R]c1ccc(NC(=O)c2ccccc2Nc2ccc([R])cc2C(=O)O)cc1</smiles>

II<smiles>NC([OH2+])=S</smiles>

Thiourea

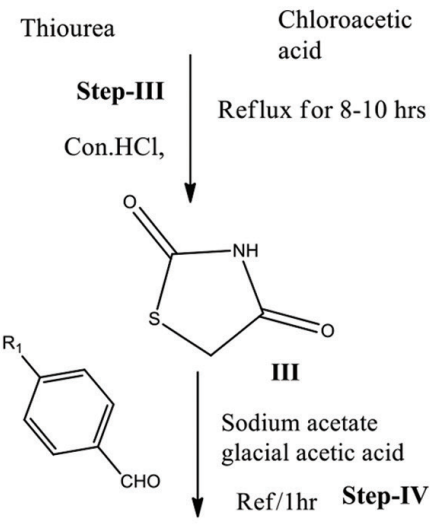

Step-V<smiles>CCCCCC(=O)Cl</smiles>

Reflux $/ 5 \mathrm{hrs}$

gla.acetic acid

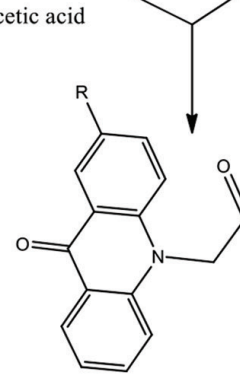<smiles>[R]c1ccc(/C=C2/SC(=O)NC2=O)cc1</smiles>

IV

$\mathrm{R}=\mathrm{H}, \mathrm{Cl}$

$\mathrm{R}_{1}=\mathrm{H}, \mathrm{CH}_{3}, \mathrm{NO}_{2}, \mathrm{Cl},-\mathrm{N}\left(\mathrm{CH}_{3}\right)_{2}, \mathrm{OH}$<smiles>[R7]c1ccc(/C=C2\SC(=O)N(C(C)=S)C2=O)cc1</smiles>

\section{$5 a-51$}

Scheme 
Table 1: Physical data of compounds 5a-51

\begin{tabular}{|c|c|c|c|c|c|c|c|c|c|}
\hline S. No. & $\mathbf{R}$ & $\mathrm{R}_{1}$ & $\mathbf{R}_{2}$ & $\mathbf{R}_{3}$ & $\mathbf{R}_{4}$ & Mol. for & M.P $\left({ }^{\circ} \mathrm{C}\right)$ & $\%$ yield & $\mathbf{R f}$ \\
\hline $5 a$ & $-\mathrm{N}\left(\mathrm{CH}_{3}\right)_{2}$ & $\mathrm{H}$ & $\mathrm{H}$ & $\mathrm{H}$ & $\mathrm{H}$ & $\mathrm{C}_{2} \mathrm{H}_{21} \mathrm{~N}_{2} \mathrm{O}_{4} \mathrm{~S}$ & $250-252$ & 76 & 0.73 \\
\hline $5 b$ & $-\mathrm{OCH}_{3}{ }^{3-2}$ & $-\mathrm{OCH}_{3}$ & $-\mathrm{OCH}_{3}$ & $\mathrm{H}$ & $\mathrm{H}$ & $\mathrm{C}_{28} \mathrm{H}_{22} \mathrm{~N}_{2} \mathrm{O}_{7} \mathrm{~S}$ & $297-299$ & 71 & 0.68 \\
\hline $5 c$ & $\mathrm{H}^{3}$ & $\mathrm{H}^{3}$ & $\mathrm{H}^{3}$ & $\mathrm{H}$ & $\mathrm{H}$ & $\mathrm{C}_{25}^{28} \mathrm{H}_{15} \mathrm{~N}_{2} \mathrm{O}_{4} \mathrm{SCl}$ & $>300^{\circ} \mathrm{C}$ & 64 & 0.76 \\
\hline $5 \mathrm{~d}$ & $\mathrm{Cl}$ & $\mathrm{H}$ & $\mathrm{H}$ & $\mathrm{H}$ & $\mathrm{H}$ & $\mathrm{C}_{25}^{25} \mathrm{H}_{15} \mathrm{~N}_{2} \mathrm{O}_{4} \mathrm{SCl}$ & $287-289$ & 72 & 0.59 \\
\hline $5 e$ & $\mathrm{H}$ & $\mathrm{H}$ & $\mathrm{H}$ & $\mathrm{Cl}$ & $\mathrm{H}$ & $\mathrm{C}_{26} \mathrm{H}_{18} \mathrm{~N}_{2} \mathrm{O}_{4} \mathrm{~S}$ & $261-263$ & 68 & 0.73 \\
\hline $5 \mathrm{f}$ & $\mathrm{CH}_{3}$ & $\mathrm{H}$ & $\mathrm{H}$ & $\mathrm{H}$ & $\mathrm{H}$ & $\mathrm{C}_{26}^{26} \mathrm{H}_{18}^{18} \mathrm{~N}_{2}^{2} \mathrm{O}_{4}^{4} \mathrm{~S}$ & $269-271$ & 72 & 0.77 \\
\hline $5 g$ & $\mathrm{H}$ & $\mathrm{NO}_{2}$ & $\mathrm{H}$ & $\mathrm{H}$ & $\mathrm{H}$ & $\mathrm{C}_{25} \mathrm{H}_{15} \mathrm{~N}_{3} \mathrm{O}_{4} \mathrm{~S}$ & $280-283$ & 68 & 0.73 \\
\hline $5 \mathrm{~h}$ & $-\mathrm{OCH}_{3}$ & $-\mathrm{OCH}_{3}$ & $\mathrm{H}$ & $\mathrm{H}$ & $\mathrm{H}$ & $\mathrm{C}_{27}^{25} \mathrm{H}_{20}^{15} \mathrm{~N}_{2}^{3} \mathrm{O}_{6}^{4} \mathrm{~S}$ & $238-240$ & 74 & 0.67 \\
\hline $5 i$ & $\mathrm{NO}_{2}$ & $\mathrm{H}$ & $\mathrm{H}$ & $\mathrm{H}$ & $\mathrm{H}$ & $\mathrm{C}_{25} \mathrm{H}_{15} \mathrm{~N}_{3} \mathrm{O}_{6} \mathrm{~S}$ & $243-246$ & 66 & 0.82 \\
\hline $5 \mathrm{j}$ & $-\mathrm{NH}-\mathrm{C}_{2} \mathrm{H}_{5}$ & $\mathrm{H}$ & $\mathrm{H}$ & $\mathrm{H}$ & $\mathrm{H}$ & $\mathrm{C}_{27} \mathrm{H}_{21} \mathrm{~N}_{3} \mathrm{O}_{4} \mathrm{~S}$ & $211-213$ & 70 & 0.59 \\
\hline $5 \mathrm{k}$ & $-\mathrm{N}\left(\mathrm{CH}_{3}\right)_{2}^{3}$ & $\mathrm{H}$ & $\mathrm{H}$ & $\mathrm{H}$ & $\mathrm{CH}_{3}$ & $\mathrm{C}_{28} \mathrm{H}_{23} \mathrm{~N}_{3} \mathrm{O}_{4}^{4} \mathrm{~S}$ & $263-266$ & 74 & 0.62 \\
\hline 51 & $-\mathrm{OCH}_{3}$ & $-\mathrm{OCH}_{3}$ & $-\mathrm{OCH}_{3}$ & $\mathrm{H}$ & $\mathrm{CH}_{3}$ & $\mathrm{C}_{29} \mathrm{H}_{24} \mathrm{~N}_{2} \mathrm{O}_{6} \mathrm{~S}$ & $205-207$ & 69 & 0.75 \\
\hline
\end{tabular}

NMR (DMSO) $\delta \delta$ ppm: 8.11 (s, 1H, benzylidene), 7.89-7.80 (d, $2 \mathrm{H}, \mathrm{Ar}-\mathrm{H}$ ), 7.79-7.76 (d, 2H, Ar-H), 7.69-7.67(d, 2H, Ar-H), 7.66-7.57 (t, 2H, Ar-H), 7.56-7.53 (t, 2H, Ar-H), 7.53-7.11 (d, 2H, Ar-H), 4.18-4.16 (s, 2H, - $\mathrm{CH}_{2}-$ ), 1.94-1.81 (S, 6H, $-\mathrm{N}\left(\mathrm{CH}_{3}\right)_{2}$; mass (LC-MS): $\mathrm{m} / \mathrm{z}$ 483(M), 484(M + 1, 100\%).

5b.(Z)-3-(2-(9-0xoacridin-10(9H)-yl)acetyl)-5-(benzylidene) thiazolidine-2,4-dione

M.P. 297-299 ${ }^{\circ}$ C; Mol. formula: $\mathrm{C}_{28} \mathrm{H}_{22} \mathrm{~N}_{2} \mathrm{O}_{7}$ S, yield 71\%, 3023 (C-H Str, Ar), 2897, 2945, 2805 (C-H Str, Aliphatic), 2300 (C-S-C Str), 1713, 1690 (C=0 Str, thiazolidine-dione), 1503 ( $\mathrm{C}=\mathrm{CH}$ Str), 1423 (C=C Str, Ar), 1104 (C-N Str). ${ }^{1} \mathrm{H}$ NMR (DMSO) $\delta \delta$ ppm: 8.35 (s, 1H, benzylidene), 8.06-8.04 (d, 2H, Ar-H), 7.94-7.92 (d, 2H, Ar-H), 7.82-7.821 (d, 2H, Ar-H), 7.77$7.75(\mathrm{t}, 2 \mathrm{H}, \mathrm{Ar}-\mathrm{H}), 7.17-7.14(\mathrm{t}, 2 \mathrm{H}, \mathrm{Ar}-\mathrm{H}), 6.88-6.86(\mathrm{t}, 3 \mathrm{H}, \mathrm{Ar}-\mathrm{H}), 4.29-$ $4.28\left(\mathrm{~s}, 2 \mathrm{H},-\mathrm{CH}_{2}-\right.$ ); mass (LC-MS): $\mathrm{m} / \mathrm{z} 440(\mathrm{M}), 441(\mathrm{M}+1,100 \%)$.

\section{5c.((Z)-3-(2-(9-0xoacridin-10(9H)-yl)acetyl)-5-(4-chlorobenzylidene)} thiazo lidine-2,4-dione

M.P. $>300^{\circ} \mathrm{C}$; Mol. formula: $\mathrm{C}_{25} \mathrm{H}_{15} \mathrm{~N}_{2} \mathrm{O}_{4} \mathrm{SCl}$, yield $64 \%$, IR $\left(v \mathrm{~cm}^{-1}\right)$ : 3096 (C-H Str, Ar), 2960, 2905, 2895 (C-H Str, Aliphatic), 2324 (C-S-C Str), 1720, 1698 (C=O Str, thiazolidine-dione), 1526 (C=CH Str), 1454 (C=C Str, Ar), 1108 (C-N Str), 855 (C-Cl Str, Ar). ${ }^{1} \mathrm{H}$ NMR (DMSO) $\delta \delta$ ppm: 8.45 (s, 1H, benzylidene), 8.37-8.31 (d, 2H, Ar-H), 8.15-8.09 (d, 2H, Ar-H), 8.05-8.01 (d, 2H, Ar-H), 7.94-7.89 (d, 2H, Ar-H), 7.84-7.78 (t, 2H, Ar-H), 7.75-7.09 (t, 2H, Ar-H), 4.506-4.504 (s, 2H, $-\mathrm{CH}_{2}-$ ); mass (LC-MS): $\mathrm{m} / \mathrm{z}$ $474(\mathrm{M}), 475(\mathrm{M}+1,100 \%), 476(\mathrm{M}+2)$.

5d. (Z)-3-(2-(9-0xoacridin-10(9H)-yl) acetyl)-5- (2-chloro benzylidene) thiazo lidine-2,4-dione

M.P. $287-289^{\circ} \mathrm{C}$; Mol. formula: $\mathrm{C}_{25} \mathrm{H}_{15} \mathrm{~N}_{2} \mathrm{O}_{4} \mathrm{SCl}$, yield $72 \%$. IR $\left(v \mathrm{~cm}^{-1}\right)$ : 3003 (C-H Str, Ar), 2945, 2930, 2868 (C-H Str, Aliphatic), 2304 (C-S-C Str), 1704, 1686 (C=0 Str, thiazolidine-dione), 1506 (C=CH Str), 1443 (C=C Str, Ar), 1115 (C-N Str), 798 (C-Cl Str, Ar). ${ }^{1} \mathrm{H}$ NMR (DMSO) $\delta \delta$ ppm: 8.36 (s, 1H, benzylidene), 8.29-8.14 (d, 2H, Ar-H), 7.88-7.84 (d, $2 \mathrm{H}, \mathrm{Ar}-\mathrm{H}$ ), 7.79-7.77 (d, 2H, Ar-H), 7.69-7.67 (t, 2H, Ar-H), 7.55-7.45 (t, 2H, Ar-H), 7.41-7.10 (t, 2H, Ar-H), 4.29-4.25 (s, 2H, $-\mathrm{CH}_{2}-$ ); mass (LC-MS): $\mathrm{m} / \mathrm{z} 474$ (M), 475 (M + 1, 100\%), 476 (M + 2, 30\%).

5e. (Z)-3-(2-(9-0xoacridin-10(9H)-yl)acetyl)-5-(4-methylbenzylidene) thiazo lidine-2,4-dione

M.P. M.P. 261-263우 ; Mol. formula: $\mathrm{C}_{26} \mathrm{H}_{18} \mathrm{~N}_{2} \mathrm{O}_{4}$ S, yield $68 \%$. IR $\left(v \mathrm{~cm}^{-1}\right)$ : 3038 (C-H Str, Ar), 2932, 2911, 2873 (C-H Str, Aliphatic), 2311 (C-S-C Str), 1716, 1671 (C=0 Str, thiazolidine-dione), 1520 (C=CH Str), 1465 (C=C Str, Ar), 1107 (C-N Str). ${ }^{1} \mathrm{H}$ NMR (DMSO) $\delta \delta$ ppm: 8.37 (s, $1 \mathrm{H}$, benzylidene), 8.31-8.10 (d, 2H, Ar-H), 7.88-7.84 (t, 2H, Ar-H), 7.687.63 (t, 2H, Ar-H), 7.58-7.57 (d, 2H, Ar-H), 7.55-7.51 (d, 2H, Ar-H), 7.14-7.13 (d, 2H, Ar-H), 4.15-4.13 (s, 2H, $-\mathrm{CH}_{2}$ ), 1.87-1.83 (S, 3H, $-\mathrm{CH}_{3}$ ); mass (LC-MS): $\mathrm{m} / \mathrm{z}$ 454(M), 455(M + 1, 100\%).

\section{Pharmacological activity: Anticancer activity [20]}

Cell viability was evaluated by the MTT assay with three independent experiments with six concentrations of compounds in triplicates. Cells were trypsinized and perform the trypan blue assay to know viable cells

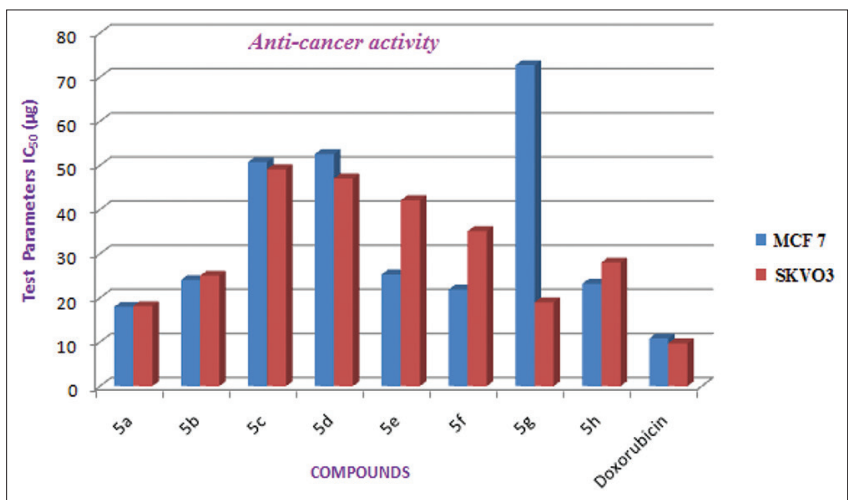

Fig. 1: Graphical representation of novel acridine derivatives on MCF-7 and SKVO3 cells

in cell suspension. Cells were counted by hemocytometer and seeded at density of $5.0 \times 10^{3}$ cells/well in $100 \mu$ media in 96-well plate culture medium and incubated overnight at $37^{\circ} \mathrm{C}$. After incubation, take off the old media and add fresh media $100 \mu \mathrm{l}$ with different concentrations of test compound in labeled wells in 96 plates. After $48 \mathrm{~h}$, discard the drug solution and add the fresh medic with MTT solution $\left(0.5 \mathrm{mg} / \mathrm{mL}^{-1}\right)$ be added to each well and plates were incubated at $37^{\circ} \mathrm{C}$ for $3 \mathrm{~h}$. At the end of incubation time, precipitates are formed as a result of the decrease of the MTT salt to chromophore Formosan crystals by the cells with metabolically active mitochondria. The optical density of solubilized crystals in DMSO was measured at $570 \mathrm{~nm}$ on a microplate reader.

The percentage growth inhibition was calculated using the following formula and concentration of test drug essential to slow down cell growth by $50 \%$ values is generated from the dose- response curves for each cell line by with origin software.

$$
\% \text { Inhibition }=\frac{100(\text { Control }- \text { Treatment })}{\text { Control }}
$$

\section{RESULTS AND DISCUSSION}

The present work involves the reaction between condensation of acridine and various 2, 4-Thiazolidine-2,4-dione derivatives $(2 \mathrm{a}-2 \mathrm{~h})$ with chloroacetyl chloride to give a novel acridine derivatives (5a-5l), respectively. The synthesized compounds were screened for antimicrobial and anticancer activities. The structures of all the newly synthesized compounds were characterized as $5 \mathrm{a}-5 \mathrm{l}$ on the basis of satisfactory analytical and spectral data including IR, LC-MASS, and ${ }^{1} \mathrm{H}-\mathrm{NMR}$ data.

\section{Anticancer activity}

Novel acridine derivatives (5a-5l) were evaluated for cytotoxicity against human breast cancer cells (MCF7) and human ovarian 
Table 2: Cytotoxic activity of novel acridine derivatives on MCF-7 and SKVO3 cell

\begin{tabular}{lll}
\hline Sample description & \multicolumn{2}{l}{ Test parameters $\mathrm{IC}_{\mathbf{5 0}}(\boldsymbol{\mu g})$} \\
\cline { 2 - 3 } & MCF7 & SKVO3 \\
\hline $5 \mathrm{a}$ & 17.98 & 18.12 \\
$5 \mathrm{~b}$ & 24.07 & 25.05 \\
$5 \mathrm{c}$ & 50.75 & 49.15 \\
$5 \mathrm{~d}$ & 52.6 & 47.06 \\
$5 \mathrm{e}$ & 25.35 & 42.12 \\
$5 \mathrm{f}$ & 21.88 & 35.12 \\
$5 \mathrm{~g}$ & 72.72 & 19.01 \\
$5 \mathrm{~h}$ & 23.21 & 28.03 \\
Doxorubicin & 10.8 & 09.7 \\
\hline
\end{tabular}

carcinoma cell lines (SKVO3) using MTT assay, with doxorubicin as standard. Results (Table 2) proposed that both MCF7 and SKVO3 cell lines were susceptible to the evaluated compounds. Compounds $5 \mathrm{a}-51$

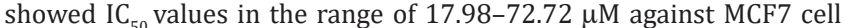
line and 18.8-49.15 $\mu \mathrm{M}$ against SKVO3 cell line. Compounds 5a, 5f, $5 \mathrm{~g}$, and $5 \mathrm{~h}$ showed good activity against both the cell lines, whereas remaining all other compounds showed moderate activity against both cell lines (Fig. 1). Whereas, remaining all other compounds showed moderate activity against both cell lines. Compounds 5 a and $5 \mathrm{~h}$ having dimethyl amine group and nitro substitution, respectively, at $4^{\text {th }}$ position. Electron releasing nature of these atoms may be the possible reason for good activity.

\section{CONCLUSION}

The objective of the present work was to synthesize, purify, characterize, and evaluate the biological action of newly synthesize structural analogs of acridine derivatives containing thiazolidine moieties. The yield of the synthesized compounds was found to be in the range from 66 to $84 \%$. In conclusion, the present study highlights the importance of acridine derivatives having various heterocyclic moiety features responsible for anticancer activities and may serve as a lead molecule for further modification to obtain clinically useful novel entities.

\section{ACKNOWLEDGMENTS}

The authors gratefully acknowledge the Center for Molecular Cancer Research, Vishnu Institute of Pharmaceutical Educational and Research, Narsapur, Medak, and Sri Venkateshwara College of Pharmacy, Madhapur, Hyderabad, for providing facilities and laboratories.

\section{CONFLICTS OF INTEREST}

The authors declare that they have no conflicts of interest.

\section{REFERENCES}

1. Kumar R, Kaur M, Kumari M. Acridine: A versatile heterocyclic nucleus. Acta Pol Pharm 2012;69:3-9.
2. Bernthsen A. Synthesis of acridines by the $[4+2]$ annulation of arynes and 2-aminoaryl ketones. Ann 1884;224:1.

3. Chen YL, Lu CM, Chen IL, Tsaoand LT, Wang JP. Synthesis and antiinflammatory evaluation of 9-anilinoacridine and 9-phenoxyacridine derivatives. J Med Chem 2002;45:4689-94.

4. Yartseva LV, Isayevand SG, Svechnikova OM. Synthesis and antiproliferative activity of acridine-sulfonamide conjugates. Farm $\mathrm{Zh}$ 2003;3:60.

5. Gamage SA, Spicer JA, Atwell GJ, Finlay GJ, Baguley BC, Denny WA. Structure-activity relationships for substituted bis(acridine-4carboxamides): A new class of anticancer agents. J Med Chem 1999;42:2383-93.

6. Kaya M, Yildirir Y, Celik GY. Synthesis and antimicrobial activities of novel bisacridine-1,8-dione derivatives Med Chem Res 2011;20:293-9.

7. Aly EI, Abadi AH. Synthesis and antitubercular activity of 6-chloro (unsubstituted)-2-methoxy-9-substituted acridine derivatives. Arch Pharm Res 2004;27:713-9.

8. Tripathi RP, Verma SS, Pandey J, Agarwal KC, Chaturvedi V, Manju YK, et al. Search of antitubercular activities in tetrahydroacridines: Synthesis and biological evaluation. Bioorg Med Chem Lett 2006;16:5144-7.

9. DiGiorgio C, DeMeo M, Chiron J, Delmas F, Nikoyan A, Jean S, et al. Synthesis and antileishmanial activities of 4,5-di-substituted acridines as compared to their 4-mono-substituted homologues. Bioorg Med Chem 2005; 13:5560

10. Kumar A, Srivastava K, Kumar SR, Puri SK, Chauhan MS. Synthesis of 9-anilinoacridine triazines as new class of hybrid antimalarial agents. Bioorg Med Chem Lett 2009;19:6996-9.

11. Tomar V, Bhattacharjee G, Kamaluddin M, Rajakumar S, Srivastava K, Puri SK. Synthesis of new chalcone derivatives containing acridinyl moiety with potential antimalarial activity. Eur J Med Chem 2010;45:745.

12. Yu XM, Ramiandrasoa F, Guetzoyan F, Pradines B, Quintino E, Gadelle D, et al. Synthesis and biological evaluation of acridine derivatives as antimalarial agents. Chemmedchem 2012;7:587-605.

13. Gupta HC, Jaiswal V. Recent developments in the synthesis and biological activity of acridine/acridone analogues. Indian J Heterocycl Chem 2010;19:409.

14. Tonelli M, Vettoretti G, Tasso B, Novelli F, Boido V, Sparatore F, et al. Acridine derivatives as anti-BVDV agents. Antivir Res 2011;91:133-41.

15. Srivastava A, Nizamuddin A. Synthesis and fungicidal activity of some acridine derivatives. Indian J Heterocycl Chem 2004;13:261-4.

16. Vinayak MG, Dhamak KB, Kotade KB. Synthesis, antimicrobial and antiinflammatory activity of novel acridine and acridone derivatives. Eur J Pharm Med Res 2016;3:454-9.

17. Cavalluzzi MM, Bruno C, Lentini G, Lovece A, Catalano A, Carocci A, et al. One-step synthesis of homochiral O-aryl and O-heteroaryl mandelic acids and their use as efficient $1 \mathrm{H}$ NMR chiral solvating agents. Tetrahedron Asymmetry 2009;20:1984-91.

18. Rajyalakshmi G, Narsimha RA, Sarangapani M. Synthesis, characterization and anticancer activity of certain 3-(4-(5-mecapto-1, 3, 4-oxadiazole2yl) phenylimino) indole-2-one derivatives Saudi Pharm J 2011;19:153-8.

19. Leena KP, Subin MZ, Deepthy CH. In silico design, synthesis and characterization of some novel benzothiazole derivatives as anticancer agents. Asian J Pharm Clin Res 2017;10:50-15.

20. Venkanna A, Siva B, Poornima B, Vadaparthi PR, Prasad KR, Reddy KA, et al. Phytochemical investigation of sesquiterpenes from the fruits of Schisandra chinensis and their cytotoxic activity. Fitoterapia 2014;95:102-8. 